\title{
Modern Nomadic Schools \\ for Small-Numbered Indigenous Peoples \\ in the North of the Republic \\ of Sakha (Yakutia)
}

\author{
Marina Kh. Belianskaia* \\ Museum of Ethnography
}

4/1 Inzhenernaia Str., St. Petersburg, 191186, Russia

Received 25.03.2016, received in revised form 16.05.2016, accepted 24.08.2016

\begin{abstract}
The article deals with nomadic schools, one of the school education options available for children of small-numbered indigenous nations resident in the North of the Republic of Sakha (Yakutia). Supported by the government of the Republic, for several decades the research institutions of Yakutia have been developing and implementing the project of such schools, performing educating and upbringing functions without separating children from their family environment. The fundamental purpose of such education facilities is to create a basis for preserving languages and cultures of the Northern nations, thereby continuing professional succession in reindeer breeding.

The author of the article analyzes functioning of such schools in the areas of concentrated settlement of nomadic and semi-nomadic peoples of the North and Arctic districts of Yakutia.
\end{abstract}

Keywords: nations of the North, reindeer breeding, hunting, fishery, nomadic school, Arctic territory, ethnic culture, preservation of language and culture, revival, youth of the North.

DOI: 10.17516/1997-1370-2016-9-10-2342-2350.

Research area: pedagogy.

This article presents a research of one of the options of school education specifically developed for children of the Northern nations resident in the Republic of Sakha (Yakutia) (hereinafter abbreviated as $R S(Y)$ ), the nomadic school. Today such education facilities are alternative to conventional secondary schools, being one of important stages of preserving languages and cultures of the small-numbered indigenous peoples of the North of the Republic.

\section{Problem statement}

The problem of preserving and reviving languages and cultures of the small-numbered indigenous peoples of the North, aggravated with globalization and technical development in all spheres of modern life, still remains acute in our country, even though some mechanisms of ethnocultural development of such nations have been implemented on the federal level since the 1990 -s. For instance, native language studies at schools, introduction of specific disciplines,

(C) Siberian Federal University. All rights reserved

* Corresponding author E-mail address: daroma_20@mail.ru 
electives and even foundation of specialized education facilities have been persistently financed. However, the ethnic language use rate is decreasing year by year, raising the question of practicability of such measures as a whole.

Let us consider the problem of preserving the languages of the small-numbered peoples of the North, being one of the consequences of modern reindeer breeding development, based on the work carried out in the Republic of Sakha (Yakutia). In all diversity of ethnicities resident in the territory of the region, this group includes the Evenki, Evens, Dolgans, Yukagirs and Chukchi, constituting $0.3 \%$ of the population (Dannye FGS po RS (Y)...). Representatives of the ethnicities live in the places of their historical residence, in settlements where other languages dominate, activating the process of assimilation and rejection their ethnic languages and original cultures.

In the 1990-s it was common for many education experts to believe that ethnic language teaching at secondary education facilities may develop sustainable command of the language for the new generation of the Northern youth. Such statement was based on the wishes articulated by school students and their parents; for this reason, the theoretical knowledge provided by secondary schools was believed to help the new generation getting practical skills of communication in their ethnic language for everyday use. However, the statistical data of the RF Census-2002 proved the opposite. The official data proved that the command of the ethnic language of the Yakutia Evenki reduced by $7.5 \%$, with the same indicator for the Evens being 24.9\% (Dannye FGS po RS (Y)...), which proves the problems of ethnocultural development of the ethnicities, including reduction of their languages' use rate.

It is well-known that within the past 50 years a big number of the Northern ethnicities' representatives preferred living in the settlements remote from their historical economic activity. Only a small share of the population prefers traditional lifestyle, preserving their language environment as its essential condition. As a rule, preschool children from such families are always with their parents, starting school omitting nursery schools and kindergartens. Obviously, it was a challenge they could not get over during the whole process of school education. However, it included some other peculiarities important for any Northern person as such. Thus, back in the 1970-s, L. Tynel', who studied preschool education facilities of Chukotka, wrote: "Children coming to school from the tundra generally have a good command of their ethnic language, they are more industrious and independent. Such children are helpful, trustful, honest, they love nature and the land where they were born" (Tynel', 1976, p.29). Such typical features of the children brought up in the family traditions of the ethnos are still preserved; the main point is that this category of the Northern people are the potential successors of the traditional lifestyle, intending to do reindeer breeding in the future.

Let us pay some attention to the boarding schools where nomads' children study. As a rule, this category of students went to the settlements where the schools were located, and then returned home for a short summer vacation. However, in some cases children could not make it to the reindeer stopovers due to transport issues, such as low accessibility of the places where their parents were and the high price of helicopter trips. For this reason, the growing generation of the Northerners had to spend a great part of their lives away from the family, at boarding schools or with their relatives who lived in villages. Moreover, during the education process, boarding school teachers involuntarily broke the habits and skills specific for nomadic people. For instance, V.F. Afanasyev published a letter of a teacher from the EvenYukagir Primary School of Allaikhovsky District 
of Yakutia, A. Yakovleva, who wrote: "It takes long for the children to get used to the boarding school life. Very often in the mornings I found empty beds and children sleeping on the floor in their reindeer fur overcoats" (Afanasyev, 1958, p. 8) etc.

Besides education, boarding school studies have developed a complex of psychological and pedagogical problems in the reindeer breeders' children, which manifes themselves in the absence of "interaction and succession between the family and school education; the role of the family reduces to the minimum" (Kostetskiy, 1971, p. 41). As a rule, due to the departure from their common lifestyle, such children develop new cultural targets and values, based on the universal life rules with the domination of European model and prevalence of Russian or Yakut languages. It creates a situation when the Northern youth have no wish to continue the lifestyle of their families, rejecting their ethnic language as unnecessary.

However, in the past decades, some parents living nomadic or semi-nomadic lives tend to reject school education perspective for their children. In the year 2006 the author of the present article studied sociocultural environment of the indigenous population of the Nenets Autonomous Okrug, the Nenets and Izhma Komi, involving students of A.P. Pyrerka Boarding School of Naryan-Mar. During the research period the school faced situations when some parents took children home after four years of studies, as in their opinion the skills of reading and writing in Russian the children had got were enough for a reindeer breeder. They believed that further education would separate the children from reindeer breeding and family as a whole. As they said, "Who would we pass on our deer if our children don't know how to take care of them!" (Belianskaia: PMA, 2006).

Generally speaking, in the 1990-s Russian society faced the problem of preserving languages and cultures of the Northern ethnicities. Teachers, researchers and representatives of the Northern nations of the RS (Y) claimed the necessity to find the best option for close cooperation between school and family not to interfere into the common nomadic life rhythm of the children, not to separate them from the family and ethnic environment, at the same time giving them the opportunity of getting education conforming to the general national standard. A.F. Golovin suggested that at the present stage one should speak not of revival, but of forming a new education system for the small-numbered peoples of the North (Golovin, 2004, p. 45).

\section{Official support and project development}

Since the late 1990-s, Scientific Research Institute of the National Schools of the Republic and the Institute of the Problems of SmallNumbered Peoples of the North of Siberian Branch of Russian Academy of Sciences (hereinafter referred to as IPSPN SB RAS), supported by the Ministry of Education of the RS (Y), Department for the Affairs of the Peoples of the RS (Y) have been developing scientific substantiation for alternative education of reindeer breeders' children with regard to the changing society and needs of the population. They spoke of a nomadic school which would support preservation and further development of languages and cultures of the Northern nations of the Republic. It was also planned to create sufficient conditions for the professional succession of generations and to provide children with education conforming to the modern standards of secondary education facilities.

At the initial stage the project had many opponents; the mass media of the republic opened multiple discussions on the topic. For instance, the nomadic schools were claimed not to be able to handle school curriculum with a 
teacher with a single profile; it was announced that "such schools would bring up unsocialized individuals unable to adapt to the modern society" (Golovin, 2004, p. 45). However, due to some understandable reasons the contradictions between different opinions concerning school education in the Arctic districts of Yakutia, populated, majorly, by small-numbered Northern nations, began to fade until they disappeared completely. In that time the schools of the region were in critical condition, had no computers or teaching aids, and, first of all, were in desperate need for human resources. Thus, in the academic year 1998-99 many Northern and Arctic schools of Yakutia had open vacancies: out of 287 vacancies, only 58 were occupied (Tekushchie materialy 2000 g.). Young teachers refused to go there due to the remoteness from the capital and the administrative centres, unsatisfactory living conditions, insufficiency of salary compared to the costs of essential goods etc.

Therefore, the initiative of the Northern intellectuals and Association of the SmallNumbered Indigenous Peoples of the North of the RS (Y) found support of the administrative bodies of the republic, thanks to which the specialized research institutions united their experience to develop a nomadic school project.

\section{Nomadic school model and beginning of large-scale implementation of the project}

IPSPN SB RAS and Research Institute of the National Schools of the RS (Y) made up a nomadic school concept, supplying it with a teaching aids' package, thereby providing the grounds for work of such schools; practical implementation of the project began with passing the sufficient regulatory documents (Gabysheva, 2004, p. 9). Thus, in 1996 the Ministry of Education of the Republic passed the Nomadic Schools Decree, and developed a project for the national development program for such schools in the RS (Y) for the period of 2004-2006 (Tarabukina, 2004, p. 38). As a result, nomadic school models and their variations, correlating with the multinational composition of the population of Yakutia, diverse climatic conditions and certain living environment, were established (Model' kochevoy shkoly..., 2006).

Let us study the suggested nomadic school options for preschool and school students of the Northern and Arctic uluses of Yakutia. They include:

\section{- Nomadic}

\section{kindergarten-school,}

consolidating reindeer breeders' families, preserving the succession of generations in traditional economic activities and the original lifestyle of the small-numbered indigenous peoples of the North.

- Community school corresponds to a regular stationary ungraded school with an additional liability of attracting community members and students' families into the education process.

- Tutorial school with the teachers visiting their students' families during the period of studies while the reindeer breeders are at reindeer stopovers.

- Taiga school is based on the parents' teaching their children according to the curriculum, combined with control sessions at the assigned school.

- Stationary nomadic school is based on tasks and purposes of an ethnocultural centre. Students of such school gather at the nomadic camp for some time to obtain practical skills of reindeer breeding and reindeer farm management.

- Nomadic school network has a consultant teacher working with several schools, moving together with them. The studies are both intramural and extramural.

- Nomadic summer school educates the students who have no command of their ethnic 
language, plunging them into the language and culture environment during summer.

According to the "Nomadic education facilities' development concept" (2005) and "RF national policy concept" (2006), all models of nomadic secondary education facilities are intended to preserve and ensure equal development of ethnic languages and traditional cultures of the peoples of Russia. In 2008, a law "On nomadic schools" was passed in Yakutia to state such schools to be the initial stage of education for improvement of the life standards of small-numbered peoples of the RF and RS (Y). (Model' kochevoy shkoly..., 2006). The works of research institutions of Yakutsk summarized the existing experience in the area, while the support received from the republic's government ensured unhindered implementation of the project. This way, some alternative education facilities targeted at the nomadic population of the republic were created.

However, the first nomadic schools appeared in Yakutia back in the 1990-s for the Even children of Aldansky, Olenioksky and Momsky Districts. The development challenges brought two of them to closure at the very beginning of the work. One of the factors was the time of their foundation; a significant role was played by economic problems, absence of available study programs, lack of multi-profile teachers and other factors. Besides, the psychology of the people used to uniform school education models both at the district education bodies of the regions and among the representatives of the Northern nations living in the republic, complicated the process. However, due to the consequences of absence of teachers in Northern and Arctic schools, this option of teaching proved to be sustainable and practicable.

Thus, according to the statistics of the year 2002, representatives of the Northern nations lived in 69 settlements of 20 administrative territorial entities, constituting 61.1 thousand people. 21 thousand of them were engaged in traditional economic activities, such as reindeer breeding, hunting and fishery, working in reindeer herds, indigenous communities, their fishing areas, living nomadic or semi-nomadic life. Within the mentioned time the Evenki had around 3225 children of school and preschool age; the Evens had 2158 (Gabysheva, 2004, p. 9). It is obvious that the parents engaged in traditional household faced the problem of providing their children with sufficient education, which required selection of an education facility, a boarding school or a nomadic school. At that time there were seven nomadic schools successfully performing their functions (Model' kochevoy shkoly..., 2006). Those were four Evenki nomadic schools and three Even ones, open at the farming areas and indigenous communities, their centre being settlement schools with the number of students between 7 and 15 .

\section{RS (Y) nomadic schools' activity analysis}

Speaking of the modern model of such education facility, let us pay some attention to the history of school education in the North of the country in the Soviet times. It is well-known that in that period there also were some nomadic schools for Northern peoples, founded in the period of Soviet system development when the government took multiple measures to involve Northern peoples into the new lifestyle. The schools were opened in 1925-1926 (Krongauz, 1958, p. 37), and in 1927 such schools were widely spread in almost all Northern regions of the country, though later some of them were closed, as boarding schools began to dominate (Kostetsky, 1971, p. 40).

Among the reasons for the nomadic schools' closure, there were some objective and subjective factors. Generally speaking, 
the state school education system faced some inextricable difficulties, such as absence of study programs and teaching aids in the languages of the Northern people, inability of students to communicate in Russian, inability of teachers to speak their students' languages, the teachers' inadaptability to the nomadic lifestyle and the absence of teachers belonging to the Northern ethnicities.

Today the situation in Yakutia is different, and we may speak of some results achieved by the education facilities located in the places of residence of the Northern peoples of the Republic.

For instance, in Ugut and Amma areas of Aldansky District, there are two schools functioning since 1992, located in special buildings attached to Khatystyr secondary school $90 \mathrm{~km}$ away from Ugut and $180 \mathrm{~km}$ away from Amma. In those schools, there are 18 students and four teachers (Tarabukina, 2004, p. 39). The main problem of the schools is class scheduling for groups and individual students to match the working cycle or reindeer breeders. To solve it, teachers make up their study and teaching plans with the help of parents and members of the community who are assigned responsible for teaching practical classes. For this reason, each teacher has a multi-profile education, and each of them regularly attends advanced qualification courses in Yakutsk. In the year 2004 both schools were officially registered as legal entities (Baisheva, Donskoy et al., 2012, p. 137) obtaining the official status of an education facility. Administration of the municipal entity of Aldansky District approves of the nomadic schools' work; S.V. Egorova, working at one of the schools, claims that such schools are necessary for the Northern peoples, providing practical opportunity for the preservation of language and culture of the Evenki living in the area (Rol' molodezhi v sokhranenii..., 2013, p.2).
The Arctic Zone of Yakutia has specific conditions determined by natural and geographic peculiarities, that influence the development of nomadic schools in that part of the Republic. For instance, a nomadic kindergarten-school Kueneleken, a branch of Kharyalakh secondary school, has been working in Olenioksky District since 1991. However, the distance from the stationary school at the administrative centre to the nomadic kindergarten-school is $50 \mathrm{~km}$, which is a challenge for keeping in touch, as during winter this distance may be covered by snowmobiles only, while during summer and autumn the main means of transport there is a helicopter. In Kueneleken there are two teachers working with seven students, two of which are preschoolers. The children study at the stationary school from October to January, and from January to May teachers join the students and migrate with them. Classes were given in a special tent, insulated with fur and heated with an iron oven; there was local heating and electric illumination supplied by a mobile power generator. Besides compulsory school disciplines, the students also study Basic Reindeer Breeding with practical classes, Applied Arts and Sewing, and Ethnic Sports. The education is intended to provide the children with labour training, introduce them to traditional hunting and reindeer breeding. In February 2016, within the framework of a pilot project run by the Ministry of Education of the RS (Y), in Kharyyalakh village the nomadic school was granted a module classroom, so now the school enjoys a well-equipped classroom with such modern facilities as a heater, electricity, TV and Internet connection, etc., making studies more comfortable.

Primary Nergey Even School in Kobiaysky District of the Republic was opened in 2002 as a structural subdivision of P. Lamutsky SebyanKyuel'sky Secondary School at Sebyan reindeer farm, a state unitary enterprise. At the moment 
of opening, the classes were given in a regular tarpaulin tent, with no supplies or utilities. Currently, the facility functions due to the support of the reindeer breeders who contributed their own money, as well as regular financial support of Sebyan SUE, making up the material base for the school. Today its teachers run a programme of cooperation with the students' parents, involving reindeer breeders into the process as partners (Baisheva, Donskoy et al., 2012).

\section{Kindergarten-school Urodan in} Srednekolymsky District of Yakutia educates eight children from six nomadic families. The curriculum of the school is bilingual, in Even and Russian languages; it involves deep study of the ethnic language, literature and culture of the peoples of the RS (Y).

Ulakhan-Kiuel'skaya ungraded nomadic school of Anabarsky Ulus consists of a kindergarten and a primary school, following a standard programme for such facilities. In 2006, the premises of the school were supplied with Internet connection, creating conditions for active communication and studies for the school students (Baisheva, Donskoy et al., 2012).

Analysing the facts presented above, let us remark that modern nomadic schools help stabilizing the cultural, social and economic processes in the environment of the peoples of the Yakutian North. Our conclusions are confirmed by the data provided by the Ministry of Education of the RS (Y) for academic work and discipline at the schools, which indicate conscious motivation of the students to study their ethnic language and traditional culture, as well as high success of the students in respect of the education process as a whole (Model' kochevoy shkoly..., 2006).

This way, despite some contradictory opinions concerning the RS (Y) nomadic schools teaching children from the families maintaining traditional lifestyle, such education facilities bring some positive results. For instance, two graduates of Ugut nomadic school of Aldansky District currently study at the North East Federal University in Yakutsk, majoring in humanities; three students of the same school entered a medical college and a technical lyceum in the capital of the Republic; other graduates of the nomadic school study at other vocational education facilities (Baisheva, Donskoy et al., 2012). However, the majority of students finishing nomadic schools of the Republic, stay to live with their people and stick to their traditional lifestyle, doing reindeer breeding, fishery and hunting. It would be fair to quote the opinion of the Principal of Kuenelkene school of Olenioksky Ulus, K. Kirillova, who believes that "the core of today's foremen and shepherds of the reindeer herds are nomadic school graduates" (Atakov, 2016).

\section{Conclusions}

So, today's school education of the RS (Y) turns to the education options considering the needs of various groups of the indigenous peoples living in the Republic. Reindeer breeding and fishing brigades have their nomadic schools allowing preschool and school-aged children to stay within the family, which is essential for further psychic and emotional development of the child, ethnic world outlook development, preservation of language and succession of the work experience. Similar facilities form responsibility for themselves and the future of their children in the minds of the small-numbered indigenous peoples of the North of Yakutia and, first of all, create the basis for further development of reindeer breeding. Moreover, the work carried out in the RS (Y) draws attention of other constituent entities of the Russian Federation where Northern peoples live, being one of the positive experiences in stabilization of the cultural, economic and social processes in the environment of small-numbered nations. 


\section{References}

Atakov, G.V. (2016) V Iakutii otkryli pervuiu modul'nuiu kochevuiu shkolu (fevral' 2016 g.) [The First Module Nomadic School Open in Yakutia (February 2016)]. URL: http://news.ykt.ru/article/39914 (accessed on March 15, 2016).

Afanas'ev, V.F. (1957) Shkol'nye internaty Iakutii [Boarding Schools of Yakutia]. Yakutsk.

Baisheva, S.M., Donskoy, R.I. et al. (2012) Etnosotsial'naia adaptatsiia korennykh malochislennykh narodov Severa Respubliki Sakha (Iakutiia) [Ethnosocial Adaptation of Small-Numbered Indigenous Peoples of the North of the Republic of Sakha (Yakutia)]. Novosibirsk.

Belianskaia, M.Kh. (2006) PMA-NAO, Nar'ian-Mar, Aprel' 2006.

Gabysheva, F.V. (2004) Obrazovanie malochislennykh narodov Severa v Respublike Sakha (Iakutiia) [Education of the Small-Numbered Peoples of the North in the Republic of Sakha (Yakutia)], In: Sistema obrazovaniia i korennye narody Severa: sbornik statey $i$ materialov, posviashchionnykh problemam obrazovaniia korennykh malochislennykh narodov Severa [Education System and the Indigenous Peoples of the North: collection of articles and researches dedicated to the problems of education of the smallnumbered indigenous peoples of the North]. Moscow.

Golovin, A.F. (2004) Obrazovanie na Severe kak faktor sotsial'nogo razvitiia sela i sokhraneniia etnonatsional'noy identichnosti: problemy, eksperiment, opyt [Education in the North as a Factor of Countryside Development and Ethnonational Identity Preservation: Problems, Experiment, Experience], In: Sistema obrazovaniia i korennye narody Severa: sbornik statey i materialov, posviashchionnykh problemam obrazovaniia korennykh malochislennykh narodov Severa [Education System and the Indigenous Peoples of the North: collection of articles and researches dedicated to the problems of education of the smallnumbered indigenous peoples of the North]. Moscow.

Golomareva, E.Kh. (2004) Kochevye shkoly - osnova sokhraneniia traditsionnogo uklada zhizni $i$ vozrozhdeniia olenevodstva v Oleniokskom uluse Respubliki Sakha (Iakutiia) [Nomadic Schools as Basis for Traditional Lifestyle Preservation and Reindeer Breeding Revival in Olenioksky Ulus of the Republic of Sakha (Yakutia), In: Sistema obrazovaniia i korennye narody Severa: sbornik statey i materialov, posviashchionnykh problemam obrazovaniia korennykh malochislennykh narodov Severa [Education System and the Indigenous Peoples of the North: collection of articles and researches dedicated to the problems of education of the small-numbered indigenous peoples of the North]. Moscow.

Statistical data for the RS (Ya), Volume 5. (2011) Natsional'nyy sostav $i$ vladenie iazykami naseleniia RS (Ia). URL: http: www.sakha.gov.ru/node/1873 (Accessed on May 10, 2012).

Kostetskiy, V.I. (1971) Nekotorye psikhologo-pedagogicheskie problemy vospitaniia detey v sem'e $i$ shkole narodov Kraynego Severa [Some Psychological and Pedagogical Problems of Children's Upbrinding in the Families and at Schools of the Extreme North], In: Voprosy obucheniia i vospitaniia shkol'nikov [Issues of Education and Upbringing of School Students], In: Sverdlovsk State Pedagogical Institute. Scholarly Notes: Collection 137. Sverdlovsk.

Krongauz, F.F. (1958) Kistorii shkoly na Kraynem Severe [To the History of Schools in the Extreme North], In: Prosveshchenie na sovetskom Kraynem Severe. V pomoshch uchiteliu Kraynego Severa [Education in the Soviet Extreme North. Reference Book for the Teachers of the Extreme North], Volume 8. Leningrad.

Lebedeva, A.M. (2011) Traditsionnaia sotsializatsiia rebionka v usloviiakh severnogo kochev'ia [Traditional Socialization of Children in the Northern Nomadic Life], In: Chelovek I obrazovanie [Person and Education], Moscow, No. 3 (p. 170-174).

$$
-2349-
$$


Model' kochevoy shkoly [Nomadic School Model] (2006): methodological aid. Yakutsk.

Tarabukina. E.K. (2004) O razvitii kochevykh shkol respubliki Sakha (Iakutiia) [Development of Nomadic Schools in the Republic of Sakha (Yakutia)], In: Sistema obrazovaniia i korennye narody Severa: sbornik statey i materialov, posviashchionnykh problemam obrazovaniia korennykh malochislennykh narodov Severa [Education System and the Indigenous Peoples of the North: collection of articles and researches dedicated to the problems of education of the small-numbered indigenous peoples of the North]. Moscow

Tekushchie materialy 2000 g. Departamenta po delam narodov RS (Ia) [Current Proceedings of the Department for the Affairs of the Peoples of the RS (Ya), 2000].

Rol' molodiozhi $v$ sokhranenii traditsionnykh znaniy korennykh narodov Arktiki v ramkakh Sliota olenevodov RS (Ia), posviashchennogo 100-letiiu Geroia Sotsialisticheskogo Truda I.K. Spiridonova (mart 2013 g.) [Role of Youth in Preserving Traditional Knowledge of the Indigenous Peoples of Arctic in the framework of the Congress of Reindeer Breeders of the RS (Ya) Dedicated to the $100^{\text {th }}$ Anniversary of the Hero of Socialistic Labour I.K. Spiridonov (March 2013). Yakutsk, 2013.

Tynel', L. (1976) Doshkol'noe vospitanie v rayonakh Kraynego Severa [Pre-School Education in the Extreme North Territories], In: Doshkol'noe vospitanie [Pre-School Education], (7).

\section{Современная кочевая школа \\ малочисленных народов Севера \\ Республики Саха (Якутия)}

М.Х. Белянская

Российский этнографический музей Россия, 191186, Санкт-Петербург, ул. Инженерная, д. 4/1

В статье рассматривается один из вариантов школьного образования для детей из числа коренных малочисленных народов Севера Республики Саха (Якутия) - кочевая школа. Научные учреждения Якутии при поддержке республиканского правительства на протяжении нескольких десятилетий разрабатывали и внедряли проект такой школы, ориентированной на образовательные и воспитательные функиии без отрыва детей из семейной среды. Основополагающзая иель подобных учебных заведений заключается в создании основы для сохранения языка и культуры народов Севера, что позволит продолжить профессиональную преемственность в оленеводческих хозяйствах.

Автор данного материала проводит некоторый анализ функиионирования таких школ в местах компактного проживания народов, ведущих кочевой и полукочевой образ жизни в северныхх и арктических районах Якутии.

Ключевые слова: народы Севера, оленеводство, охота, рыболовство, кочевая школа, арктическая территория, этническая культура, сохранение языка и культуры, возрождение, северная молодежь.

Научная специальность: 13.00.00 - педагогические науки. 